\title{
Teaching Management Reform and Perfection for Agricultural Colleges and Universities under Credit System
}

\author{
Li Hong \\ College of Food Science and Engineering, Jilin Agricultural University, Changchun, 130118, China
}

Keywords: Credit system; General; Teaching management; Reform

\begin{abstract}
The attempts to perform credit system reform are efficient ways for general colleges and universities to make breakthroughs and achieve better development. Credit system refers to the teaching management system under which the students voluntarily choose the courses they want to enroll and evaluations will be carried out based on credits. The students' performance will be evaluated by Grade Point Average. The students can only graduate after they get certain amounts of credits. When we explore and implement the credit system, there have appeared some new problems to be addressed for the teaching management of general colleges and universities. To solve these problems, the author of this paper put forward some countermeasures and suggestions for improving and perfecting the teaching management of colleges and universities under the credit system.
\end{abstract}

\section{Introduction}

It has been 20 years since our country started to explore the reforms of credit system. Most colleges and universities of higher education have established the credit management system. Credit system, as a new and innovative attempt for the teaching management reform in colleges and universities, can stimulate the students' passion, promote the sharing of teaching resources and establishing competition platform. Under the credit system, the teaching management in colleges and universities should match the environment, the core system, the behaviors of the main body and many other challenges. From the outcome of credit system, we can judge that it fits the condition of China and current higher education. Through such management system, the teaching in colleges and universities of our country can be facilitated. However, with in-depth development of socialist economy and higher education, the condition and requirements change correspondingly. The schoolyear credit system which is generally carried out now has shown some problems such as it cannot adapt to the latest social development..

\section{Introduction of Credit System}

Credit system is a modern teaching management system firstly emerged in the west. Under this system, students can voluntarily choose the courses they want to enroll. Their performance and learning quantities will be evaluated based on credits. The accumulated GPA will be used for evaluating their performance. And the students need to get the required credits to graduate. The credit system can be divided into two types: complete credit system and schoolyear credit system. Now, most colleges and universities in our country mainly use the schoolyear credit system.

Under the credit system, the teaching management in colleges and universities shows the following characteristics: first, voluntary course-choosing. The colleges and universities will offer many optional courses based on the social and professional requirements. They give the students the right to choose. At the beginning of the semester, the students can choose the courses and teachers based on their own interest and needs. Second, the credit system is very flexible. Students only need to get the required credits in different modules to graduate. The restrictions of time, such as three, four or five years, will no longer exist. The system values the actual skills and knowledge the students master. Third, students can show their own willingness and interest under credit system. Within a certain range, the students can choose the courses of their interest voluntarily. If they can get all the credits required by the corresponding departments, they will be able to get the graduate certificate. Therefore, some excellent or outstanding students can not only fulfill the credits required by his own 
major, but also choose the courses for a second degree. As a result, the credit system helps to break the limits in colleges and universities and better connects different disciplines. The students can form a diversified, integrated and reasonable knowledge structure.

\section{Existed Problems of Teaching Management in Agricultural Colleges and Universities under Credit System}

The Thoughts of the Teaching Affair Management Team are Lagged-behind. In order to keep the teaching affairs in the university in good order, the management of teaching affairs must be enhanced. The credit system changes the past single and static teaching management model into current multiple and dynamic model. Much influence has been asserted on the learning system in colleges, course-choosing system and teaching management plans. However, due to the increasing serious trend of more and more complicated administrative procedures in colleges, some staff of teaching management are very lagged-behind in terms of ideology, knowledge, service, informatization, technology, and so on. They cannot adapt to the needs of credit system reform, thus restricting the development of efficient and high-level teaching management.

Weak Teaching Force in Colleges and Universities Makes it Difficult to Fulfill the Needs of the Students. Most colleges and universities apply the schoolyear teaching management system. When organization teaching activities, they apply uniform teaching plan, syllabus, textbooks, etc. The credit system, to some extent, changes the situation. But the premise for applying credit system is that the college or university should be able to set up many optional courses so that the students can voluntarily choose what they want to enroll in. In this case, for the same subjects, different categories or different levels of courses should be provided to meet the diversified needs of the students. However, many colleges and universities now lack the excellent teachers to set up these courses which can intrigue the students. So, it is very difficult for the colleges and universities to fully explore the great potential and innovation ability of students, which is a bottleneck for the credit system reform in colleges and universities.

The Students have too much Freedom in Choosing Courses, which Leads to the Poor Learning Quality. After the implementation of credit system, the colleges and universities have given the students relatively enough freedom to choose the courses they want to be a part of as they wish. In this case, the students can choose the courses and teachers they like without the limit of majors, grades, departments, even universities. With such freedom, there are some bad phenomenon. For example: some students only choose what they're interested in and choose the courses too randomly. They favor some particular subjects and the knowledge structure they build is not scientific and reasonable, which is not beneficial for their overall development; some other students only choose the simple courses to get enough credits for graduation, which will also do harm to their personal growth; some students choose the courses blindly and miss many useful courses. There are many problems concerning course-choosing including: missing, replacement, no-choosing and quit-choosing. These all endanger the teaching goals and corresponding management.

\section{Measures to Perfecting and Improving Teaching Management in Agricultural Colleges and Universities under the Credit System.}

To Perfect the Education and Teaching Management Methods. The human-oriented higher education is to improve the students' quality and culture talents of good comprehensive quality. Stereotypes, inflexibility and lack of human-oriented teaching management will not adapt to the credit system reform. Therefore, when general colleges and universities implement and perfect the credit system, they should always stick to the educational principle of human-oriented teaching. They should continue to prioritize the all-round and healthy development of students. They should provide student with rights and freedom for course-choosing in higher education so as to promote students' self-development and the realization of self-value. In this way, the students will be able to pursue a happy life in the future life. All these aspects should be integrated. The teaching management staff should care, respect and understand students' interest and needs, actively build the teaching 
management mechanism focusing on students with the assistance of teachers, and realize the positive, interactive, sustainable and healthy development of teaching in colleges and universities.

To Improve the Quality and Efficiency of Teaching Management Staff is Another Key Factor for Credit System Reform. The teaching affair management staff are the "performer" of the credit system evaluation. Therefore, much efforts must be done to establish a strong team of teaching affair management staff. Their knowledge structure should be enhanced and their service and management ability should be improved. First, we should strengthen their political and ideological education so as to improve their political sense, professional ethics and work attitudes. Only in this way can they really adapt to the credit system reform. Second, we should carry out more activities for learning and training. The teaching affair management staff should be equipped with the advanced teaching management theories, know about useful models and have a good understanding of future development in this area with good ability in analysis and innovative management. Third, we should improve the psychological quality of teaching affair management staff and enhance their ability in coordination and overall management. While nurturing their innovation spirit, we should explore ways to improve the teaching management level in colleges and universities.

Perfect the Instructor System and Course-Choosing System, Provide More Guidance for Students in Course-choosing. Due the factors of study goals and plans, teaching conditions, information imbalance, inadequate knowledge and poor self-planning ability of students, during the implementation of credit system, many students find it difficult to understand the courses and teachers they want to choose well. As a result, some students blindly choose the courses, which we cannot call it true freedom. In order to avoid the problems such as over-choosing, inadequate choosing, wrong choosing, missed choosing and repeated choosing, in compulsory implementation of credit system, the instructor system should be established in time to better guide and help the students. In the meantime, the modern information software and management technology should be fully applied to perfect the function of the course-choosing software in management, reminding, supervision and coordination. Continuous perfection of the course-choosing system will help optimize the students' knowledge structure and overall abilities.

\section{Conclusion}

At present, the higher education in our country has transformed elite education to mass education. The overall quality of the students has been greatly enhanced. During the process, the credit system reform played a significant role and asserted much influence. However, as a new teaching management reform system introduced by our country from other countries for colleges and universities, there is still much to explore about the credit system. There will be inevitably some problems. The basis for intensifying the educational reform in higher education and finding an innovative method is to stimulate the students' passion, promoting personalized education and facilitating the sharing of teaching resources so as to perfect the knowledge structure of students, establish a good platform for competitions, and improve the quality of teaching force in colleges and universities. It has become the inevitable trend for the teaching management system reform in colleges and universities. In our country, when we carry out the credit system, there lack enough teaching management conditions or supporting mechanisms; the course structure is not reasonable enough; there are not enough resources for course-choosing; and the students' course-choosing is not reasonable or scientific enough. These are all difficulties we have. The author of this paper hope that the system can be optimized from various aspects to improve the quality of talents we cultivate in our country. However, no matter how hard we try to reform, improve or perfect the system, it shall be understood that the core of credit system reform is human, that is to say, we should stick to the principle of human-oriented education. On this basis, we will take actual measures to improve and perfect the teaching management models in colleges and universities, respect the personalized development of students, and realize the educational concepts of "teaching the students based on their own advantages and disadvantages". 


\section{References}

[1] Tian Haixia, Lu Jiaying. Reform and Perfection of Teaching Management in Colleges and Universities under Flexible Credit System [J]. Guide for Scientific and Technological Innovation, $2009,12: 138$.

[2] Zhang Haixia. Reform and Perfection of Teaching Management Model under Credit System-Taking Music Teaching in Colleges and Universities as an Example. [J]. Diverse Art. 2009, S1:204-206.

[3] Zhang Yan. Discussion on the Establishment of Supervision System for Teaching Quality in Colleges and Universities [J]. Education and Exploration, 2013, 03:58-60.

[4] Luo Jing. Reform and Perfection of the Teaching Management for Ideological and Political Theories in Colleges and Universities under Credit System [J]. China Vocational Education, 2013, 18:69. 